Article history : Received : 12.04 .2020 Revised : 11.05 .2020 Accepted : 28.05.2020

\section{Comparison on condition and packaging materials for better storage of onion seeds}

\author{
Debashis Manna, Tapan Kumar Maity ${ }^{1}$ and Asit Kumar Basu ${ }^{2}$
}

Members of the Research Forum

Associated Authors:

${ }^{1}$ Department of Vegetable Crops, Bidhan Chandra Krishi Viswavidyalaya, Mohanpur, Nadia (W.B.) India

${ }^{2}$ Department of Seed Science and Technology, Bidhan Chandra Krishi Viswavidyalaya, Mohanpur, Nadia (W.B.) India
Author for correspondence : Debashis Manna

Department of Vegetable Crops, Bidhan Chandra Krishi Viswavidyalaya, Mohanpur, Nadia (W.B.) India Email : debashismanna137@gmail.com
ABSTRACT : Fresh harvested onion seeds dried to 6.54 per cent seed moisture content were stored in four various packaging materials under two different storage conditions at laboratory of Seed Science and Technology Department, Faculty of Agriculture, Bidhan Chandra Krishi Viswavidyalaya, Mohanpur, Nadia, West Bengal, to identify the storage environment and packaging materials for better storage of seed. The seeds stored under cold storage condition recorded higher germination, rate of germination, seedling dry weight, vigour index, field emergence and moisture content $(80.71 \%, 24.93,18.61 \mathrm{mg}, 1148.80,71.29 \%, 8.07 \%$, respectively) compared to the seeds stored under room temperature condition and On the other hand Seeds packed in glass container recorded better results regarding said attributes $(86.75 \%, 25.99$, $18.56 \mathrm{mg}, 1246.67,74.50 \%$ and $5.73 \%$, respectively) as compare to other packaging materials at the end of six months of storage. The interaction effects of packaging materials and storage conditions also shows marked impact on onion seed storage. It can be concluded that, onion seeds packed in glass container, polythene bag or aluminium foil and stored under cold storage condition maintained better seed quality over a period of six months of storage.

KEY WORDS : Onion seed, Vigour index, Rate of germination, Cold storage

HOW TO CITE THIS ARTICLE : Manna, Debashis, Maity, Tapan Kumar and Basu, Asit Kumar (2020). Comparison on condition and packaging materials for better storage of onion seeds. Asian J. Hort., 15(1) : 15-25, DOI : 10.15740/HAS/TAJH/15.1/15-25. Copyright@ 2020 : Hind Agri -Horticultural Society 